\title{
Propiomazine Hydrochloride
}

National Cancer Institute

\section{Source}

National Cancer Institute. Propiomazine Hydrochloride. NCI Thesaurus. Code C66487.

The hydrochloride salt form of propiomazine, a phenothiazine derivative and atypical antipsychotic agent with sedative, antiemetic and antipsychotic activities. Propiomazine binds to a variety of receptors, including alpha1, dopamine, histamine $\mathrm{H} 1$, muscarinic, and serotonin type 2 (5-HT2) receptors. Propiomazine exerts its antiemetic and sedative effects through antagonism at histamine $\mathrm{H} 1$ receptors; Its antipsychotic effect is attributed to antagonistic activities at dopamine and 5-HT2 receptors. 